\title{
FLOTRAN による CFD の工学問通への道用”
}

\section{宮田悟志**}

Application of CFD to Engıneering Problems using FLOTRAN /

Satoshı MIYATA

Key words FEM, CFD, FDM, FVM nonlinear analysis, boundary condition

\section{1.はじめに}

CFD (Computational Fluıd Dynamics, 計算流体力学) といら言葉は, 多くの人にとっては馿染みの薄いものと思 われる. またこ存知の方にしても，広く日常的に使用され るノールといらよりは，特定のリサーチのために専門的研 究者か使用するテクニノクであるといら印象を持っている のてはないたろらか しかし現在 CFDは，実験による測 定や可視化か困難な，装置内の現象を予測し，その効率を 向上させるための有効な手段の一つとして使用され始めて いる CFDを効果的に利用することかてきれは，エンノ ニアは製品のプロトタイプを作成する以前の段階におい て，流速，圧力，温度分布なとを予測することかてきる

しかしこのことは実験の必要性・重要性を否定するもの てはない、むしろ “適切”にCFDを利用するためには， 実験結果から得られるテータか重要となるケースかしはし ば存在する. このことは一見, 前述の CFD の利点と矛盾 する印象を与学るか，どちらも事実てある

本稿ては熱梳体解析ソフトウェア FLOTRAN ${ }^{1)}$ を使用 し，有限要素法による CFD の適用例を紹介するか，同時 に, 実際に解析を行う上て問題となる点についても解説す る. FLOTRAN は米国 ANSYS, Inc 社か, 開発・販売を 行う汎用熱统体解析プログラムてある

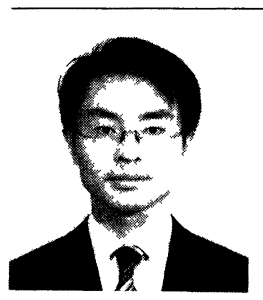

* 原稿受付 平成 8 年 6 月 4 日

** サイハ不ノトノステム(株)（東京都文京区大塚 2-15-6, 二,セ偣拆ル) 1991 年日本大学生産工学部数理工学科卒 同 年サイハ不ノトノステム(株)入社 現在テクニ カルサナートスタ,フとして, 凡用流体解析フ ロクラムFLOTRAN と Fire の業務に従事 日本数値流体力学会正会員

\section{CFD コードの内側}

$\mathrm{CFD}$ コートかその内部て数值的に解く支配方程式は, 質量保存則, 運動量保存則, エ不ルキー保存則の 3 つか基 本となる 粘性を考慮した流れては運動量保存則として, ナヒェ・ストークス (Navier Stokes) 方程式か広く使用 されている.ナヒェ・ストークス方程式は二階の非線形偏 微分方程式て, 流れにより運動量か輸送される移流作用と 分子粘性により輸送される拡散作用を表す，流れの運動方 程式てある 運動方程式右辺の外力には, 遠心力, 重力, 浮力, 流れから生しる圧力勾配なとか含をれる十七ェ・ ストークス方程式はその強い非線形性のため, 厳密解を得 ることか可能なのは, 幾つかの理想化された問題に限られ る CFD に応用される有限要素法（以下 FEM）の考兄 方は以下の通りてある.

\section{1 流れ場の離散化}

流れ場の離散化には通常の FEM て使用される三角形や 四面体要素昆在の非構造メノノュも使用されるか, 領域す へてを規則的な格子状要素て離散化する，有限差分法（後 述）て用いられる, 構造格子と呼ばれるメノノュ系も使用 される.

\section{2 離散化スキーム}

偏微分方程式てあるナヒェ・ストークス方程式は, 離散 化を経て有限個の代数方程式系へと変換され, 最終的には 代数行列の解去を使用して解かれる FEM による CFD ては，離散化スキームとして，カラーキン重み付き残差法 か多く使用されるこの点は構造解析等て使用される FEM と同様てある.たたし移流作用を表す項を離散化す る際には注意か必要となる 二階の微分項（例㝋ば払散作 用を表す項）はカラーキン失によって適切に表現すること 
ができるが，一階の微分項となる移流項では，流れの上流 側の情報を強く取り込む上流法（風上法）と呼ばれる考兄 方が必要になる。

\section{3 代数方程式系の解法}

連立代数方程式系として表された流れの支配方程式は， 代数行列の解法により解かれる.

初期の有限要素法 CFD プログラムではガウスの消去法 などの直接解法を用い, 連成された連続の式と運動方程式 を解いて，流速と圧力を計算していた．この方法は，概念 的にシンプルでプログラムのコーディングも簡単である反 面, 計算時間, 必要メモリーサイズといった点で, コン ピュータへの負荷が非常に大きくなる.

現在の CFD では, 反復型の行列解法と, 支配方程式系 の各変数に対して分離解法 ${ }^{2)}$ を採用することで, 計算効率 を高めている.

\section{3. 有限要素法で CFD を行うメリットと適用例}

構造物の静的・動的挙動, 熱, 磁場の解析等で, FEM は既に馴染み深い存在であるが，CFDに拈いては，有限 差分法 (Finite Difference Method; 以下 FDM) や有限体 積法 (Finite Volume Method; 以下 FVM) が支配的な位 置を占めている.

FDM, FVM が流体解析で中心的な存在である理由は CFDの歴史的経緯とあわせて, 計算の高速性や, コンパ クトなデータ構造, 誤差や安定性の評価が行いやすい等の 優れた特徵によるものである. しかしこれらの特徵は, 使 用する格子*の構造性に依存するところが大で，この理由 から古典的な FDM やFVM では, 曲面を含む形状への適 用には難があった．例として古典的な構造格子による円周 りの離散化を，図 1 に示す. 図で示された程度の要素分割 数では，円の曲率を表現するのには不十分であることが分 かる. また円付近の格子分割の影響が前後・上下方向へと 領域端まで波及してしまっている. FEMの場合, メッ シュの構造性といった制約が無いため，図 2 のようなメッ シュが作成できる. 曲面への適応性・要素分割の周囲への 波及, 双方の点で全く問題がない。このような優れた形状 適合性が, FEM が FDM/FVM 主流の流体解析へ適用さ れた主要な動機であった。

現在ではFDM やFVM も，境界適合格子法やマルチブ ロック法3)などの格子生成テクニックを使用し，曲面に拉 ける適応性を高めている. 特に最新の FVM では, 図 3 に 示されるような非構造格子も可能なプログラムもある. そ のため, 依然大さな利点であるとは言え, 形状適合性は以 前程は CFDにあえて FEM を導入する動機とはならなく なりつつある。

\footnotetext{
* FDM/FVMにおけるメッシュの呼称.
}

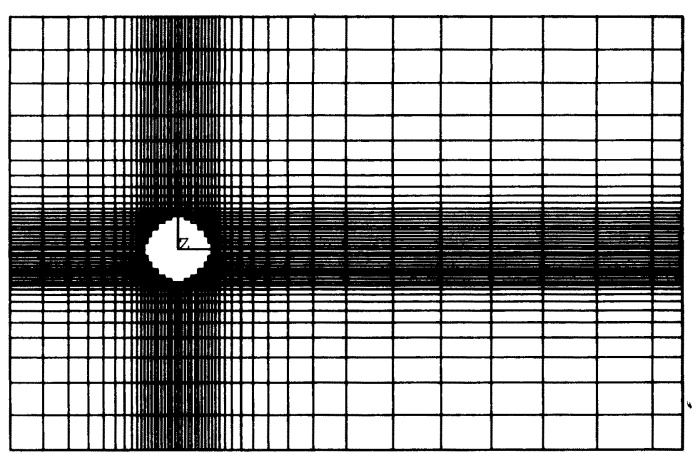

図 1 古典的な差分法（FDM）による構造格子

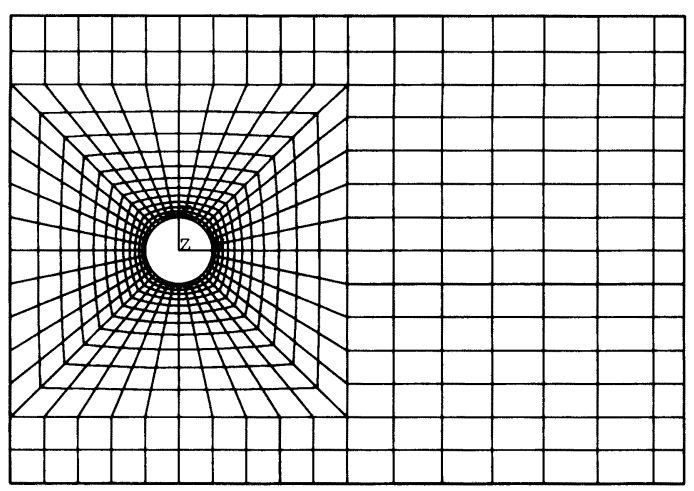

図 2 有限要素法（FEM）による非構造格子

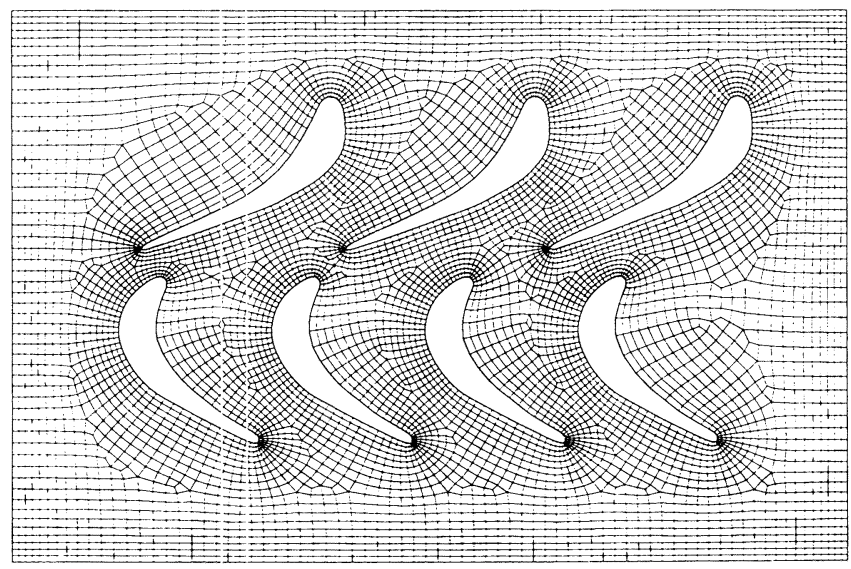

図 3 最新有限体積法（FVM）による非構造格子 （オーストリア AVL List 社, Fire version 6.2 b)

しかし近年では，データ・操作性の統一，固体場と流体 場の連成解析といった点から FEM による CFD が評価さ れ始めている. FEM による熱・構造解析システムで成功 したューザが更なる解析システムの充実を図り, 流体解析 の導入を検討するケースである．例えば流体力に起因する 動的な圧力荷重による構造解析, 流体と磁場の連成等の複 雑な場と場の連成問題がその対象である. 図 4, 図 5, 図 6 はFLOTRAN と, 有限要素解析プログラム ANSYS と の連成解析の事例である. 解析対象は 2 次元で, パイプの 絞り部にバルブが半開きになっているという問題設定であ る. FLOTRAN によりバルブ周りの流れ場（図4）を計算 し, 得られた固体表面の圧力分布（図 5) から，ANSYS 


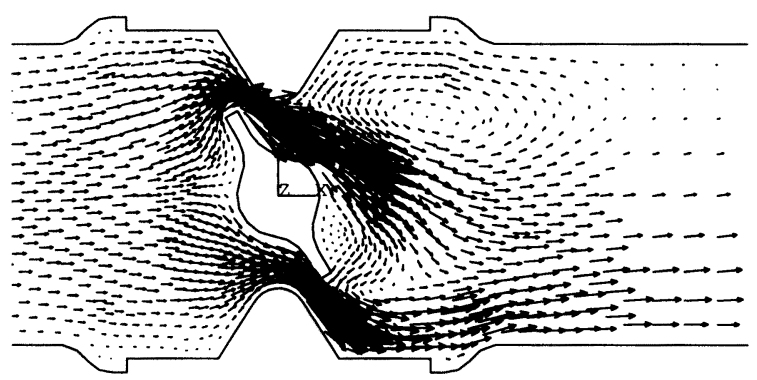

図 4 FLOTRAN により計算された流れ場

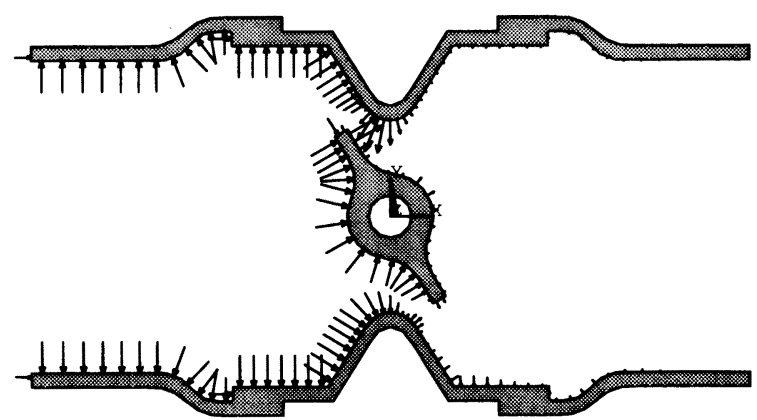

図 5 図 4 より得られた圧力分布（固体表面上のみ表示）

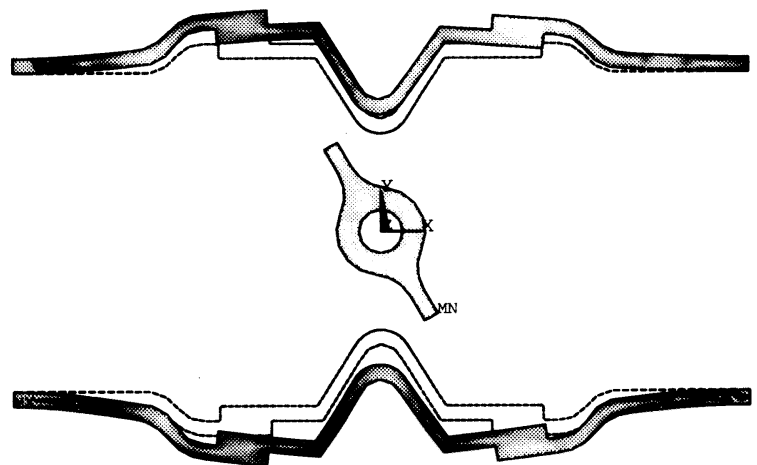

図 6 ANSYS の線形構造計算ソルバーによる応力と变位の計算 結果

の線形構造解析ソルバーによりパイプとバルブの構造解析 を行っている(図6). FLOTRAN, ANSYS は共に有限 要素法によるプログラムといらだけではなく, 同一開発元 による連成解析を意識したプログラムであることから, 同 一のユーザインタフェース・データベースの下で非常に容 易に連成解析を実現することが可能である.

\section{CFD プログラム使用上の.問題点}

では流体解析の専門家以外のユーザが, CFD プログラ ムを使用した際に直面する問題は何であろらか. 典型的な 例として前章 3 の熱・構造解析で成功を納めたューザを想 定する. 解析の実行経験は十分だが，そのほとんどは線形 解析であると仮定する. この場合遭遇する, 典型的な問題 としては，以下のものが考えられる.

（1）適切な境界条件の指定

（2）計算実行のための適切なソルバーパラメータ指定

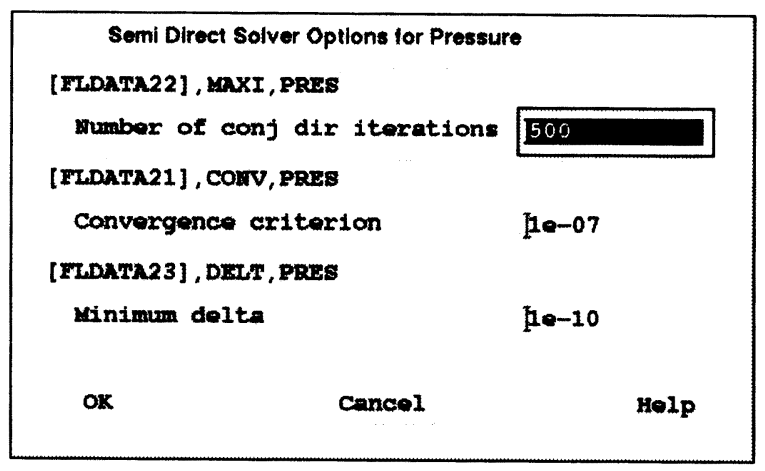

図 7 ソルバーパラメータの指定（図は圧力行列ソルバーのパラ メータ指定）

（3）計算結果の収束の判定

これらの問題は FEM による CFD プログラム固有の問 題ではなく，すべての CFD プログラムに対して共通する 問題である. また（2）と（3）はCFD プログラム以外で も，収束計算の必要なすべての非線形解析で，大なり小な り問題となる．線形計算に持いては，ューザはプログラム 使用時にこれらの点を意識する必要がほとんどないため, 広範な線形解析での経験も，この (2), (3) の解決の知見と はなり得ない.これらの問題に関しては原則的な指針は存 在するのだが，実用上有効な指針を得るためには，解析モ デルや流れ場の性質を検討することが必要である。なぜな ら数值解法としての収束 $\left.{ }^{4}\right)$ は, 従属変数の変化率や, 代数 行列ソルバーの内部的な残差, 場に出入りするフラックス 等を調べることで定性的に知ることができるが，定量的な 面（例えば残差の大きさと流れ場の変化の対応）は, 個々 の問題に依存するためである. 全くの同一問題であって も，収束計算による残差値の推移は使用するメッシュの密 度に依存し異なる。図 7 はFLOTRAN でのソルバーパラ メータ指定画面の例，図 8 は収束計算の推移に伴う残差の 出力例である.

以下では流れの計算で顕著な (1) の境界条件の問題につ いて掘り下げて解説する.

\section{1 適切な境界条件とは？}

CFD の有限要素モデルを作成する際には，どのような 境界条件を与えるべきかで，非常に苦労することがある. そしてこの事実は，冒頭「はじめに」で述べた，「実験や 可視化が困難な流れ場の様子を知るのに有効な CFDを効 果的に使ら上に拈いて，実験から得られるデータが重要な 意味を持つ」という問題の典型例である.

分かりやすい例として, 先に図 4〜6で示したバルブ周 りの流れを考える，必要となる境界条件は，

（1）上流境界条件（流入条件）

（2）下流境界条件（流出条件）

（3）壁条件

の 3 つである. この内（3）の壁条件の指定に関しては， ほ とんど自明であり通常は問題となることはない，問題が生 


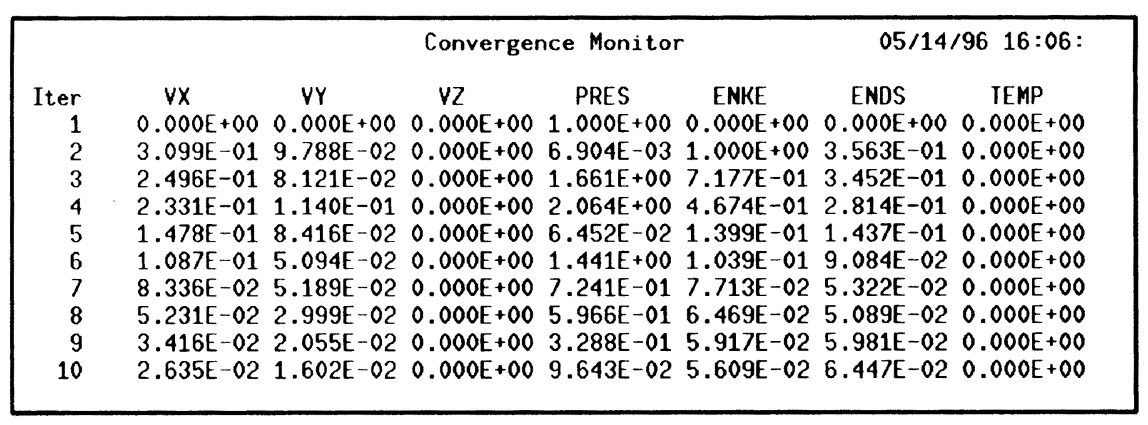

図 8 モニタされる収束判定情報の一つ（計算中の各自由度の相対残差の推移）

\section{3 CFD で実験・計測值の果たす 役割}

では一様な流れとなるまでには，ど の程度の大きさの領域を採れば十分な のであろらか。この問に解答を与えて くれるのが実験による測定結果であ る. 装置中心や物体周囲の複雑な流れ 場の精密測定は困難でも，中心から離 れた位置で流れが一様であるかどうか の測定は比較的容易である. 得られた

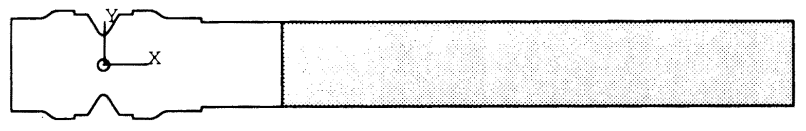

図 9 境界条件指定のために追加される領域

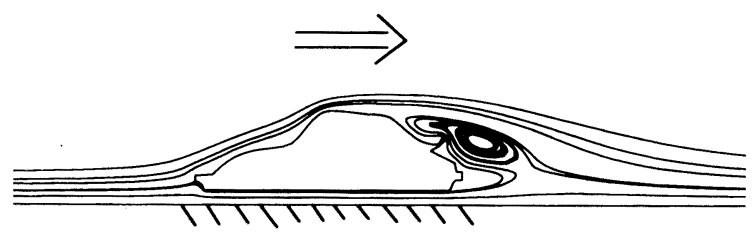

図 10 外部流れの図（車体周りの流れ）

じやすいのは（2）の下流境界条件の指定である. 流体現象 では応力や熱を伝兄る媒質そのものが流動するため, 下流 境界での各場の变数値は, 上流境界で指定した境界条件値 と流れ場形状の影響を強く受ける，そのため，「計算を実 行するためにはバルブ下流側で，境界条件を指定しなけれ ならないが，下流側の場の值は上流側の条件に依存するの で計算してみなければ分からない」といら問題に直面して しまう。

\section{2 現実的な解決法}

上記の問題の簡単で現実的な解決法は，下流側領域を流 れが安定になるまで延長するといら方法である. 図 9 に示 されるよらに網掛けの領域を付け足し，この付け足された 領域の右端を流出境界とする. 絞り部から離れるに従っ て, 流体の粘性の影響で流れは次第に一様になって行くこ とが期待できる，一様に発達しきった管内流れでは，管軸 に垂直な面内での圧力変動は, 相対的に無視できる程度に まで減少するので, 流出境界条件として一定圧力を与える ことが可能になる. 先に図 4 で示された流れ場はこのよう にして計算されたものである.

以上は管内流れの例だが，類似の問題は図 10 に示され るよらな物体周りの場合にも当てはまる. 車体後方の後流 の影響が無視できるようになるまで，下流境界を延長する ことが大切になる。 またシミュレートする車体が広大な空 間を走行しているのか, トンネル内を走行しているのかに よって，車体の上側に用意しなければならない領域の大き さは異なってくる.
結果から，必要な延長領域の大きさが決定される。一様流 れを表す境界条件を適用するのに，工学的に必要十分な基 準は，このように実験・計測により容易に提供されるので ある.

上記の例以外にも, 実験・計測により得られる情報が, 効果的に数值計算を行う上で役立つ場面が多々ある.

例之ば，流れ場が定常的らしいことが測定結果から分 かっていれば，定常アルゴリズムの使用により速やかに定 常解を得ることが期待できる．またその逆に，非定常的な 流れ場に定常アルゴリズムを適用してしまい，不安定な収 束状態や計算の発散の原因追求に何日も頭を悩ますといっ たことも避けることができるよらになる．また 4 章冒頭で 触れた問題 (3) の定量的収束基準の評価にも, 実験・計測 から得られる情報は大きく役立つ.

\section{5. ま と め}

流れの数值解法である CFD は, 近年ますますその適用 範囲を広げつつあり, 反応・燃焼・多相流れ等これまで取 り組まれていた分野以外にも，磁性流体，流体音響問題と その適用範囲を拡大させ，成果を挙げている．しかしその 一方で，本稿で指摘したよらな点が問題となって CFD の 導入に失敗する事例も見受けられる. 支配方程式の強い非 線形性と, 補助的に使用される関係式が必ずしも現象の普 遍的モデルとなってはいない事実が, 純理論的な問題の解 決を困難にしている.これらの数理モデルに依存する問題 の解決は, 今後の研究の進展が期待される所である. 有限 要素モデルの作成, ソルバーパラメータの決定, 計算結果 の評価の各段階で, 実験・計測から得られる情報を適当に 取り込むことが, 安定で効率良く流れの数值計算を行ら上 で，今後とも重要と考学られる.

\section{参 考 文 献}

1) Compuflo Inc. ed. : FLOTRAN Theoretical Manual, ANSYS, Inc., (1992).

2）スハス V. パタンカー（水谷幸夫, 幸月正司訳）：コンピュー タによる熱移動と流れの数值解析, 第 6 章 流れ場の計算, 共立出版，（1985）130～139.

3）保原 充, 大宮司久明編：数値流体力学, 第 8 章 格子形成 法, 東京大学出版会, (1992) 191 192.

4） G. E. Forsythe, W. R. Waso (藤野精一訳)：偏微分方程式の 差分法による近似解法，吉岡書店，（1968）27～30, 62６6. 